\title{
Old age and physical beauty among elderly women: a conversation between women
}

Thais Caroline Fin'

Marilene Rodrigues Portella ${ }^{2}$

Silvana Alba Scortegagna ${ }^{3}$

Abstract

The concern with body care, image, and aesthetics in the context of ideals of beauty is a subject of great interest to people. A descriptive exploratory study with a qualitative approach was carried out with a group of 60 -year-old women, aiming to discover their perception of physical beauty and the meaning addressed to it in old age. The focus group method was used in data collection and analysis. The results indicated that 60 -year-old women recognize beauty based on social standards, even if they are from different sociocultural realities. They establish a judgment of taste based on what they perceive as pleasant to see, feel, and observe. The aesthetic experience of an individual reveals a duality of images that are appreciated and depreciated, while beauty in old age means caring for oneself and one's relationships. The results offer evidence for health professionals in the structuring of therapeutic plans and educational actions focused on the aging process, especially in a female context.

\footnotetext{
Universidade de Passo Fundo (UPF), Faculdade de Medicina. Passo Fundo, Rio Grande do Sul, Brasil.

2 Universidade de Passo Fundo (UPF), Instituto de Ciências Biológicas. Passo Fundo, Rio Grande do Sul, Brasil.

3 Universidade de Passo Fundo (UPF), Instituto de Filosofia e Ciências Humanas. Passo Fundo, Rio Grande do Sul, Brasil.
}

Keywords: Women. Female. Body. Old Age. Beauty. 


\section{INTRODUCTION}

From the beginnings of civilization physical beauty has been a goal sought by human beings, especially women. However, what was thought beautiful in previous decades is not necessarily considered so today. The curvaceous bodies and full forms that were contemplated and portrayed by the great artists of the past are today admired for the value of the art but not as a reference of physical beauty for contemporary women.

Today women are confronted with images that glorify youth and the exaltation of thinness ${ }^{1,2}$. Patterns that define beauty vary between civilizations, cultures, the historical era, and the customs of peoples ${ }^{1,3}$. However, the search for beauty persists, transcending generations, and is greatly influenced by the aesthetic standards in which it is inserted. Thus, concepts of beauty are aligned with how society behaves in relation to aesthetic standards ${ }^{4-6}$. Adopting Jiminez' ${ }^{7}$ reading of aesthetics from a Kantian perspective, it can be said that society judges beauty through an impure judgment, as it attributes a concept of perfection based on the sociocultural values of the moment.

The theme of body and old age has led to the development of several studies. Some authors have discussed the meaning of the body in old age when the corporal transformations that come with the aging process deviate from the standards of beauty that prevail in society ${ }^{4-6}$. Others have discussed how to live with aging in a society that values concepts such as the beauty of the body and the myth of eternal youth ${ }^{6,8}$ while at the same time seeming to avoid the experience of old age as the phase of closest proximity to death and the decrepitude of the body $y^{4,5}$.

In addition to cultural and social aspects, it has been found that while age and socioeconomic factors are associated with body dissatisfaction, they can also have a reverse effect. Older women may experience less dissatisfaction with the body because of their maturity, accumulation of experiences, and positive self-esteem ${ }^{9}$. Thus, dissatisfaction with the body can decrease as aging is accompanied by a change of priorities, and, as the authors explain, health and the affirmation of one's identity become more important than appearance.
For health professionals, working with such issues is both challenging and necessary, as this theme, in matters of the healthcare of women, can go beyond the scope of aesthetics and be seen as something healthy and recommendable for a pathological plan, requiring medical intervention.

Appearance can have a strong impact on the quality of life, self-esteem and social life of young and middle-aged women at any stage of life. However, taking as a starting point the examination of the perception that elderly women have regarding physical beauty, the guiding question of the present study was: "what meaning do they attribute to physical beauty in old age?". It is important that health professionals in the fields of geriatrics and gerontology consider their answers, as intervention and health promotion measures can be anchored in studies of this nature. The purpose of the present study was to describe the meaning of physical beauty in old age in order to discover the understanding that older women have about such beauty, as well as analyzing and describing the meanings that they attribute to physical beauty in old age.

\section{METHOD}

An exploratory descriptive study with a qualitative approach was carried out. The sample comprised ten women aged between 60 and 69 years. The women were married, had varying levels of schooling and socioeconomic status, and lived in a city in the countryside of the north of the state of Rio Grande do Sul. The participants were divided into two groups. The first one (FG1), was composed of five women with twelve years of schooling and over, who earned a minimum of six times the minimum salary, lived in the central urban area, and attended an open university program linked to a university. The second group (FG2), consisted of five women with an education of 1 to 8 years of schooling who earned the minimum wage, lived in peripheral urban areas, and were members of a social group for the elderly.

The delimitation of the number of participants was due to the delineation of the study and the inclusion criteria applied, which were age group, participation in projects directed at the elderly and 
different educational and socioeconomic levels. We chose the focus group (FG) method, as this technique seeks to capture the language forms, expressions and types of comments of a given segment, to achieve greater levels of understanding and achieve deeper awareness of a topic based on debates focused on specific subjects ${ }^{10}$. To form the FGs, the project was first presented to the respective coordinators, and the invitation was then extended to the groups at different times. The research proposal was also explained at this time, with a view to selecting the participants. Although the FG technique recommends a minimum of six components, each FG in the present study was composed of only five members, as adherence to the research proposal in the context from which FG1 was selected resulted in only five women, which led the researchers to opt a paired composition in FG2. When presenting the research proposal in the FG2 context, there was an excess of potential participants that met the inclusion criteria, and so an enrollment strategy was applied, establishing five places. The times, dates and locations of the FG sessions were defined in agreement with the participants and their respective coordinators. The FG meetings were independent and took place at different times, and were moderated by the researcher and as an observer, a person with full knowledge of the research project. The debate in the FG was guided by the moderator while the observer recorded verbal and non-verbal impressions with a field diary and an audio recorder. A script was adopted in accordance with the study objectives and the sessions were divided into two parts.

The initial part of the first session included the presentation of the study proposal, an explanatory reading of the Free and Informed Consent Form, and its formalization by means of a signature. The participants were then introduced, and a discussion about the theme beauty and physical beauty followed. At the beginning of the second session several images of elderly persons in various situations of daily life were shown on a large screen as a multimedia resource to stimulate the discussion about the theme of old age and beauty. Following the session of images, the question "what is beauty in old age?" was asked and then debated. Also in this session, in the second part, the imagination exercise technique me in front of the mirror was used, in which participants were invited to spend a "moment of silence", closing their eyes and imagining themselves in front of a mirror. After a few minutes, the question was then asked: What did the mirror show? In the final meeting, a synthesis of the previous meetings was presented and the data was validated. This proposed development of the sessions was applied in both the locations selected.Three meetings took place with an average duration of 90 minutes each. In order to preserve the identity and anonymity of the participants, flower codenames were distributed at the beginning of the first session.

The Gatti ${ }^{10}$ FG perspective analysis was used for the analysis and interpretation of the data. The observer's notes, the summaries gathered in the sessions and the transcripts of the meetings were collected. The process of reading and rereading this material for coding purposes then began. The frequency of mentions in these units guided the script for the interpretation of the data. The analysis took place in an interactionist dimension and the interpretation was based on the constructed reference.

The data collection period was the first semester of 2013, following the approval of the project by the Research Ethics Committee of the Universidade de Passo Fundo (Passo Fundo University), record $\mathrm{n}^{\mathrm{o}}$ 254.318. All the participants signed a FICF.

\section{RESULTS AND DISCUSSION}

The perceptions of the women regarding physical beauty in old age expressed in the focus groups converged into three categories: beauty in words; the aesthetic experience in front of a mirror (revelations about beauty and old age); and the beauty of women in old age.

\section{Physical beauty in words}

Physical beauty can be expressed in several ways. In the present study, when the participants were asked to express themselves by means of words on this theme, several expressions emerged, as shown in Figure 1. 


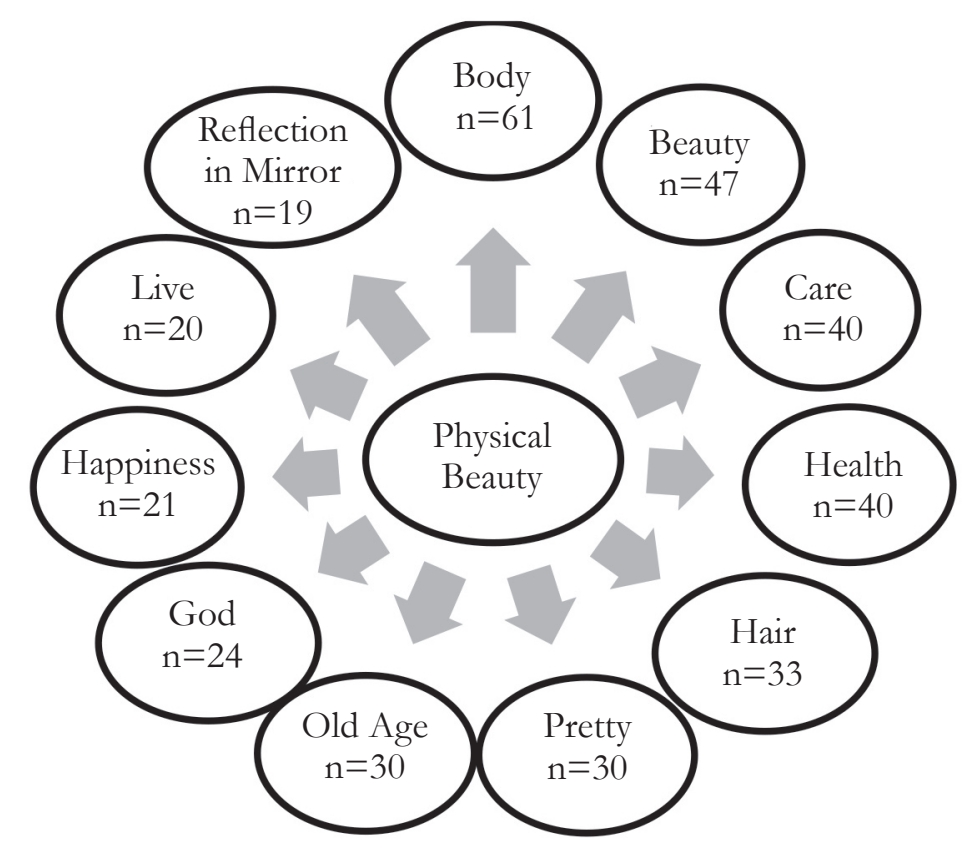

Figure 1. Physical beauty illustrated in words. Passo Fundo, Rio Grande do Sul, 2013.

The various indications regarding physical beauty evidenced in the study partly follow the thoughts of $\mathrm{Eco}^{11}$, in expressing that beauty is linked to the various adjective indicators (joy, pretty, beauty/beautiful) of what represents the sensory and imaginary visuality of people, as well as the sensations of the sublime, the marvelous and the divine (God, living). However, the human being is vulnerable to sociocultural pressures in such a way that some of the words evoked reflect beauty as a model to be met (body, appearance, health, care), a response to the social standard. Society imposes on women the condition of avoiding old age, and does so by means of varied resources ${ }^{6}$, such as rigorous care of appearance, body, styled and dyed hair, in a demonstration of avoiding old age, which was suggested to us by the indications of such words in the FG (Figure 1).

There is a more or less constant manner of acting and perceiving the world in daily life, determined by a series of psychological and social factors and processes that determine our usual perception of what is beautiful or what is beauty. Duarte $\mathrm{Jr}^{12}$ emphasizes that "what is beautiful for one is not so for another," as beauty is not an objective quality that certain objects possess. For the author, beauty inhabits the relationship that an individual maintains with an object, in this case, the body.
When dealing with physical beauty, the thoughts of Ferreira ${ }^{13}$ are worth noting. These affirm that the body is the main link between an individual and the world, is socially constructed and is a material representation of the subject versus society relationship. It is the space where symbolic conflicts represent the prevailing issues of reality in our existence. The summaries abstracted from the focus group demonstrate this:

"Everyone wants a beautiful person, slim, elegant, well dressed, with her hair done, by their side; but no one wants to be close to those who speak ill of others, are rude and bad humored; they'll never be admired [...] looking smart, with a nice hair style, wearing makeup, look how beautiful they are! What a beautiful old lady! Those who take care of their appearance get noticed in the street. Look at the pretty lady" (FG2).

In the vision of Beauvoir ${ }^{4}$, human beings never live in their natural state, because during old age, as in any age, their status is imposed by the society to which they belong.

The studies of Santos and Dias ${ }^{6}$ discuss the growing concern of women regarding the valorization of the youthful image, a healthy appearance and beauty linked to social models as an ideal to be sought after, patterns that are massively influenced by the media. 
If the social context values a thin body model, corresponding to the standard of beauty, overweight and obesity cause embarrassment. The debate between the participants included comments such as:

\begin{abstract}
"There are no clothes that look good on fat people, while all clothes look good on slim people, it's the same with big feet; I get to the store and I'm ashamed because my shoe size is 39-40. I can't buy beautiful shoes because they don't fit. My daughter took me to the store to choose some boots and I had to take the cheapest because the better ones wouldn't fit. When you look at fat people you see defects, but not in skinny people. Chubby people that aren't too fat, and that look smart are attractive, but the really fat ones and the really skinny ones are ugly" (FG2).
\end{abstract}

The common perception of women expressed in FG2 reinforces the current cultural pattern of the valuing of leanness and lipophobic culture ${ }^{1,2}$. Obesity is visually considered a problem, a feature that cannot be hidden, that clashes with beauty, and so is ugly. Perceptions about overweight are reinforced by the phenomenon of the social and cultural rejection of obesity. The shame referred to lies in the interpretation that women apply to their weight and large shoe size, a demonstration of how much the emotions are intertwined with the opinions we have about our bodies ${ }^{14}$.

The studies of Goldenberg ${ }^{15}$ warn that, in Brazil, society associates leaving the body in its natural state as synonymous with sloppiness and a lack of care, especially if the body is fat or aged. Thus, in recent decades, the concern of Brazilian women to remain young has grown absurdly because of the standard imposed by society, which emphasizes youth as an ideal.

The view and judgement elderly woman have of their bodies is guided by contemporary customs, which demand that a beautiful body should look youthful and be thin, hence clothes are designed to hide imperfections and localized fat ${ }^{2,3}$. Clothes are the packaging that veils and unveils, simulates and conceals what should be hidden.

These social requirements also occur in the intrafamilial environment, as expressed by FG1. For this group, young people demand their elderly mothers care for their appearance, thus reinforcing the constructed and diffused social model.

\begin{abstract}
"Nowadays I taking care of myself, because the children put pressure on me and they started giving me things and saying that I have to look pretty, that is, to make myself look smart, because for me anything was fine" (FG1).
\end{abstract}

Beauty is present in the essence of being and can be expressed by a person's attitudes and the way they behave. In the present study, it was noticed that the participants of the two groups made judgments about beauty, endowed with subjectivity and feeling:

"A girl with a beautiful body, not because she takes care of her appearance, but the nature of the person, we notice if she cares for her skin and her hair, but it is the friendliness behind her eyes that shows the beauty" (FG1).

"The luminous golden radiance, along with resourcefulness and femininity. The sweet expression, the rhythmic way of walking that make beauty, good character manifesting itself" (FG1).

In this alignment, there are no rules regarding the bodily model, the perception of beauty expressed in the debates comes from the behavior of the person.

"A good way of communicating, hair nicely styled, appearance, a polite person, this is physical beauty" (FG2). "Politeness and good humor. Politeness first, knowing how to treat people, always be in a good mood and don't pull faces. Making faces reflects ugliness and never beauty [...]. Ugly people don't force people away, if she is friendly, polite, knows how to treat others, she becomes beautiful" (FG2).

Reflection on the judgments given by the sexagenarian women about physical beauty was supported by the Kantian conception of the judgement of taste, which deals with adherent beauty? Kant, in the reading of Jimenez ${ }^{7}$, distinguishes two forms of beauty: the free and the adherent. In the Kantian conception ${ }^{8}$, free beauty is related to the judgment of taste, the feeling of the beautiful, while adherent beauty is linked to an end, a concept of perfection, and is considered an impure judgment. Judgment cannot depend on a desire, nor does it reduce something to the fact of being desired ${ }^{7,8}$. The judgment of taste that relates beauty, expressing its experience, communicates a disinterested and pure satisfaction. For Kant, saying something is beautiful is different from saying that it is agreeable. 
Physical beauty, described in the present study within this concept, deals with adherent beauty, as the judgment expressed in the FG is conditioned by the idea of what people should and must be. In Kant's conception, the manifestations of the women reflect an impure judgment, for they do not consider the aesthetic judgment of the beautiful and lack the pure contemplation of a work of art or an aesthetic sense of physical beauty, because the issue is the beauty of the human body, and not a truly aesthetic element.

The judgment is impure, because it expresses an interest in the manifestations of women. This interest is linked to that which is agreeable and what is good in the interaction with people of any age. The agreeable and the good have a relation with the faculty of desire. The question that arises, when one reaches old age, is what is good and agreeable to observe and what is desired of other people? What is suggested to us is that in the perception of the sexagenarian women beauty is in the way people communicate, in the communication of the "sweet expression", the "friendliness behind an expression", "politeness", or the "good humor", that we call good and agreeable. This is because, through language, the body presents itself as a bearer of meaning.

The meaning of the body is primarily the result of sociocultural factors, whose construction is interdependent with the form of interaction, thus reflecting the beauty highlighted in a context. If the sexagenarian women through their sensibility capture the feelings present in the contemporary worship of the youthful body, one can imagine how the older body is stigmatized. The judgment of taste regarding physical beauty does not follow Kantian rigor, nor is it aligned with what society establishes as a model of physical beauty: the young body, sculpted and well defined. Beauty is in what is thought agreeable to see, to feel and observe.

\section{Aesthetic experience in front of the mirror: revelations about beauty and old age}

To understand the perceptions of physical beauty in the FG and as a trigger element of the debate, an imagination exercise was carried out among the women. Believing that human expression can be understood as always being symbolic, verbal or visual, an imaginal activity was performed, with the elderly women asked to close their eyes and imagine themselves in front of a mirror. After a few moments, the following debate question was asked: What did the mirror show? The reactions were varied and loaded with feeling. The perceptions derived from the reflected image in the mirror were grouped into appreciated and depreciated images, shown in Figure 2.

Figure 2 shows that in FG1 there was a predominance of appreciated images, in which the mirror revealed the harmony and symbolism in the marks of cutaneous expression, exhibiting self-affirmation, well-being and satisfaction with the body. In FG2, however, among the low-income women living in the urban periphery a mixture of melancholy and depreciation regarding the reflected image predominated.

Pereira ${ }^{16}$, in contributing to understanding aesthetic knowledge, states that we can have an aesthetic experience in relation to any object or event, whether it is art or not, or beautiful or not, or whether it exists or not. When the sexagenarians looked at themselves in the mirror, they established an aesthetic experience with the projected image.

If anything can be an aesthetic object, then the reflected image provides an aesthetic experience in the sense proposed by Duarte $\mathrm{Jr}^{12}$, who manifests that "our feelings are touched" in an aesthetic experience. In revealing the appearance of the aging body, women confess their feelings about the aspects of the years lived, in an interweaving of beauty and ugliness.

Resignation is also expressed, as time passes and leaves marks, an appearance that is made visible by the trajectory of life. Pitanga ${ }^{17}$, argues that while these marks are inevitable, the ideal is the acceptance of the signs that come with old age in the best possible way, because, even when presenting characteristics of physical wear (wrinkled skin, a lack of tautness and firmness of the skin), these are compensated for by the inner glow of each subject. For some sexagenarians, this inner glow is the inner beauty itself, reflected in the energy and will to live, an acceptance of the signs of time and satisfaction with the appearance of the body. 


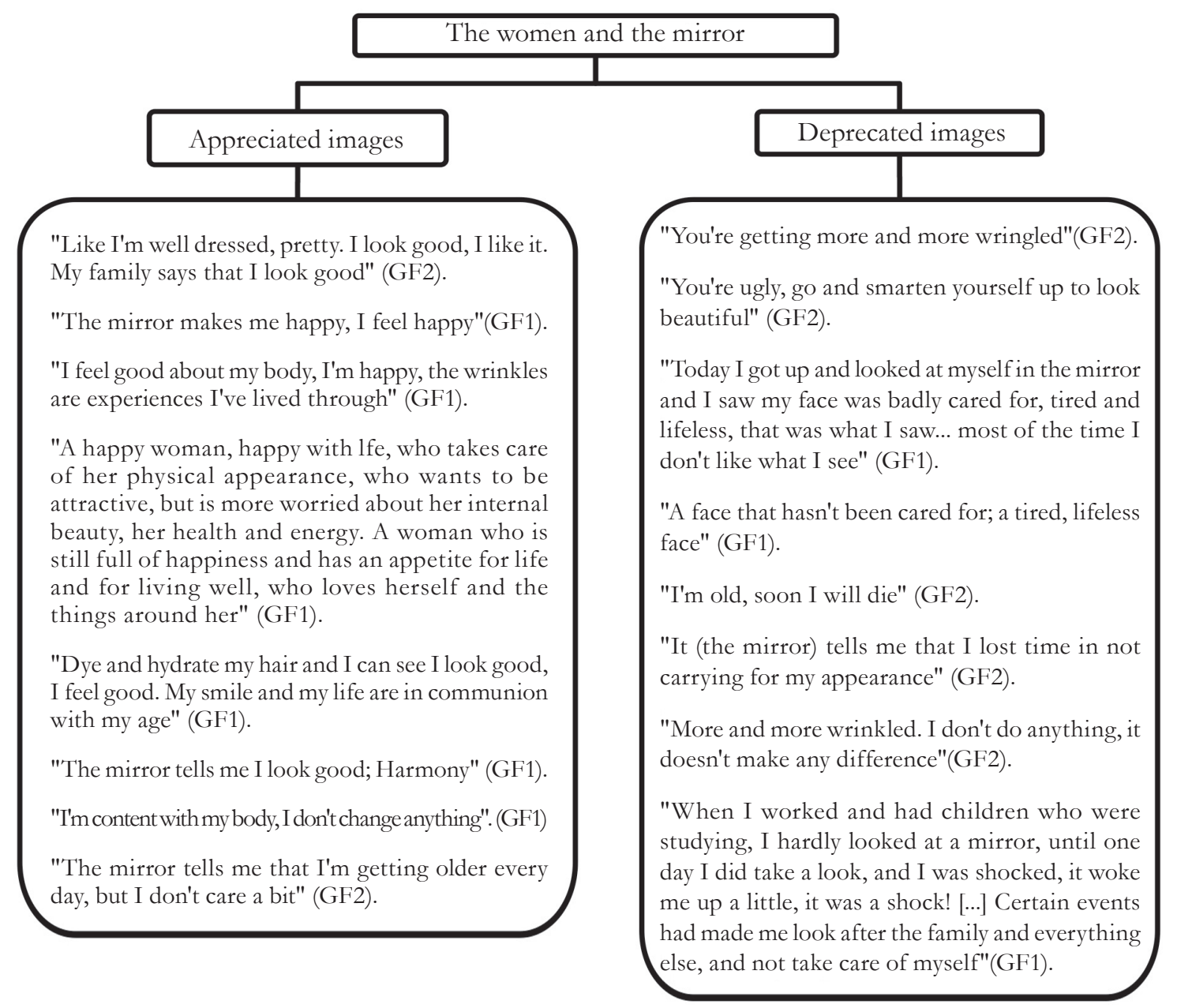

Figure 2. The revelations of the mirror. Passo Fundo, Rio Grande do Sul, 2013.

Care for one's appearance, even without the influence of the aesthetic standards applied by society, represents the self-affirmation and valorization of one's own beauty with the advance of time. For Blessmann ${ }^{5}$, women are principally responsible for changes to their image in old age. Without previous commitments, they are free to enjoy new experiences that have been deprived to them in the past, and when they reach old age, a period conducive to new discoveries and achievements begins.

If the image causes feelings of discomfort, it is because the image reflected by the mirror represents a misunderstanding and does not reflect all that we $\operatorname{are}^{18}$; it only represents us in an imaginary form and thus enables the appearance of what one does not want to see, something that is particular to each of us.

This perception of strangeness is influenced by the widespread diffusion of current aesthetic standards ${ }^{19}$, which causes a reduction in the selfesteem and quality of life of the elderly women. For them the loss of the youthful traits and physical characteristics that are so highly valued by society is a sign of decrepitude and finitude.

The aging process can be expressed in two ways, one negative and one positive. People who consider old age as a negative stage of life do so by relating it to physical and mental degeneration, as well as inactivity, incapacity, selfishness, and ugliness, factors that provoke sadness, loneliness, depression, and moodiness ${ }^{20}$. However, those who associate old age with a positive stage of life, value the physical and mental autonomy, independence, participation and integration with the beauty of the lived experience of the phase.

Schneider and Irigaray ${ }^{21}$ stress that even with so many resources that prevent disease and delay the cutaneous characteristics of old age, aging is still 
feared by many people and seen as an unpleasant stage of life. For others ${ }^{22}$, the model of a body that does not meet the current standards of beauty in society reflects a loss of social value.

In front of the mirror, the sexagenarians, unlike an individual appreciating a work of art, express different ways of understanding the aesthetic experience in the duality of the image, which is both appreciated and depreciated. In the same way, they allow an opening to the different senses of the world of human beings that live and grow old, or in other words, ways of experiencing the reality of old age. From the dialoguing of their own experiences, like the individual appreciating art, they reveal themselves before the relationship with their own experience.

\section{The beauty of women in old age}

The relationship that women have with old age is reflected in the way they interpret and attribute meaning to beauty in this phase of life. Beauty in old age was related to health and to caring for oneself as much as to love and joy. The body is the limit and the extension of our contact and relationship with the world. Beauty inhabits this relationship, as Duarte $\mathrm{Jr}^{12}$ argued. Caring for the body in old age can be a guarantee of remaining connected with the world. The body reveals the intricacies of personal history, and with this process comes transgression and the ability to react and self-assert oneself beyond appearance ${ }^{23}$. In the circularity of this process, women demonstrate satisfaction with their own bodies, breaking potential prejudices regarding the aged body, attributing to it beauty and other noble characteristics, perhaps because they are linked to another internal image of themselves, as described by Peat et al, ${ }^{9}$ which are more important and intense than their external appearance. The following comments of the FGs reflect this:

"Health, if you have health if you can do anything, is essential, physical and mental health. Harmony" (FG1)."Health encompasses everything, if you have health, you will take care of the body without depending on the opinion of others. Health is essential for the beauty of the body, as well as feeling good about yourself and other people, that's what beauty is" (FG2).
Ribeiro $^{24}$ points out that quality of life among the elderly is associated with the pleasure of having good health and encompasses several aspects of human life, among them the pleasure of interacting in society.

\begin{abstract}
"Having your health, disposition, joy, being happy, going out, having friendships, sharing, solidarity, having a job, volunteering at institutions [referring to the institutions that offer shelter to the elderly] and dancing a lot is what makes people happy... if a woman is happy, she is beautiful, this is what makes a woman beautiful. If she loves herself, she cares for her body." (FG1).
\end{abstract}

Health is an important factor for a sense of well-being and personal satisfaction of the elderly with their appearance 9 , so that successful aging occurs through the constancy of such factors $^{25}$. Comments reflecting this proposition arose during the debate:

\begin{abstract}
"First comes good health, by maintaining good practices such as diet, walking, always taking care of yourself, and if you have a problem going to the doctor" (FG2).

"Physical beauty is part of the body, of living, we have to take care of ourselves, to do things right, to do physiotherapy of the knees, otherwise we can't dance and we have to be active" (FG1).
\end{abstract}

If beauty is the property of a healthy body, a sick body presupposes ugliness. In the discussions emanating from the FG, disease is removed from the standards of beauty. "The bad thing is when you are sick, you have no desire to do anything, least of all take care of beauty" (FG2). Diseases are common occurrences of aging and thus express a relationship of reciprocity between old age and disease, which is so ingrained that it is difficult to remember that disease can affect anyone at any stage of life 5 . It is important to note that old age has been associated with several negative aspects, such as chronic diseases, dependency, frailty, disability and death ${ }^{25,26}$. It establishes, then, a relationship between illness and ugliness, explaining the requirement and the incentive of care with the passing of the years.

Moreira and Nogueira ${ }^{8}$ highlight that the issue of age is perceived by many as a personal choice. In this concept, there exist individuals who grow old and 
those who actively react against the signs of aging. Youth becomes a value to be earned and a benefit to be acquired, while old age becomes a matter of neglect on the part of those who have not engaged in motivational activities or consumed the products and services that combat aging. This is reflected in observations made in the FG:

"A woman has to look after herself, and exercise" (FG1).

"[...] health covers everything, you need to care for your body" (FG2).

"[...] use cream and take care of your diet" (FG2).

If, on one hand, when one reaches old age, care is the most important thing, on the other, there is an understanding of the participants that this care permeates the course of life:

"It is important that as a young person there is a concern with caring for your skin and your body so that when you reach this stage people do not spoil their faces with so many things" (FG1). "When you get pregnant, you can't overdo it with eating, or caring for your skin, the care has to be overall" (FG2).

The perspective of the women is in line with the thinking of Foucault ${ }^{27}$ in asserting that caring for oneself is a principle that is valid for anyone, at any time, and throughout life. Caring for oneself throughout life is characterized as a principle of the development of an individual, it must be practiced at all times of life, when one is young and one is old, during youth to prepare for life and in old age to remove the effects of time ${ }^{28}$.

Quality aging must be seen as a continuous process of learning, intellectual, emotional and psychological growth, associated with moments of pleasure and personal satisfaction24. Taking as a reference the discourse of the FGs, it can be seen, among other aspects, that beauty in old age is considered as a process that requires caring for oneself and one's intra and interpersonal relationships.

"If you don't love yourself, if you don't have love for yourself, in the first instance. If I have love I'll have optimism, health, the disposition to do what I want, but if I don't love myself my body will be ugly" (FG2).

"If you feel good about yourself, you'll live happily, of course, taking care of yourself. (FG2) You have to care for your body; you have to love yourself, you have to take care of yourself” (FG1).

Physical beauty is part of the body, we have to look after ourselves, take care of our bodies and our souls" (FG1).

In the perspective of Foucault ${ }^{27}$, the most important care one should take of oneself is an attentive look at the body and the soul. For this, it is necessary to maintain consistent attitudes about one's own self, that is, it is fundamental to pay genuine attention and continuous vigilance to the self. In the understanding of the women, one has to take care of oneself, one's body and one's soul, this is what translates into beauty in old age. As Foucault himself puts it, the principal end to propose to oneself must be sought within the individual, in relation to himself or herself ${ }^{28}$.

In order for an individual to take care of themselves, it is important to establish an intensity of self-relationships with oneself, in which they manage to consider themselves the object of knowledge and action, so their relations with themselves allow self-transformation and correction ${ }^{28}$. If beauty in old age lies in self-care, then women must follow rules, behaviors, and principles. Thus, exercising, physiotherapy, dancing, keeping moving, seeking the doctor when one does not feel well, and even volunteering are indispensable precepts for caring for oneself and, therefore, for beauty in old age.

From this perspective, the words of $\mathrm{Kant}^{8}$, that perceptions are not passive, but are synthesized by the faculty of the imagination, are invoked. Therefore, the participants of the study, when judging beauty in old age to be based in taking care of oneself, seek concordance with this judgment. According to the Kantian conception, it is not expected that everyone perceives beauty in old age, which the participants refer to, but it is conjectured that everyone should perceive it, as for the elderly woman beauty is in her singularity, in self-appreciation and in self-love, which includes caring for oneself.

The limitations of the present study are its specific sociocultural context and the reduced number of participants, which restricts extending 
the results for the purposes of generalization, making necessary further research pertinent to the subject, from the perspective of other visions.

\section{CONCLUSION}

The results of the present study allow us to conclude that the group of women, even if from different socioeconomic and cultural realities, recognize beauty as based on contemporary customs, with the influence of current esthetic standards.

Based on the Kantian conception, women's manifestations of physical beauty follow the proposition of adherent beauty, as they establish a judgment of taste in what they deem agreeable to see, to feel, and to observe. Thus, beauty is in the way people communicate, whether by a sweet, friendly expression, or by politeness in the way one treats people. It is through language that the body presents itself as a bearer of meaning.

The aesthetic experience of an expression reveals a duality between the appreciated and depreciated images expressed by different ways of understanding and feeling the reality of old age. In unveiling the appearance of the aging body, women confess their feelings towards the experiences of the years lived in an interweaving of beauty and ugliness.

Beauty in old age is considered a process that requires caring for oneself and one's relationships. It is an attentive look at the body and soul, which follows rules, conduct and principles, such as exercising, maintaining a good mood, dancing, keeping moving, seeking the doctor when one does not feel well, and even volunteering. The perception of beauty is abstracted into the uniqueness of being by appreciation and love dedicated to oneself.

If, on the one hand, a limiting factor of the study is that it reflects only one social context, not allowing the results to be extended for the purposes of generalization, on the other, a possible echo of other realities can be inferred, which can provide health professionals with indications of how to structure therapeutic plans. This includes strategies of physical and psychic care, as well as educational actions aimed at thinking about the aging process, particularly in the female dimension. The replication of the study is recommended, extending the theme to other situations in order to corroborate it or add new findings.

\section{REFERENCES}

1. Vieira CM, Turato ER. Percepções de pacientes sobre alimentação no seu processo de adoecimento crônico por síndrome metabólica: um estudo qualitativo. Rev Nutrição 2010;23(3):425-32.

2. Marshall C, Lengyel C, Utioh A. Body dissatisfaction among middle-aged and older women. Can J Diet Pract Res 2012;73(2):241-47.

3. Nascimento FDS. Velhice feminina: emoção na dança e coerção no papel de avó. Rev Bras Sociol Emoção 2011;10(30):457-506.

4. Beauvoir S. A velhice. Rio de Janeiro: Nova Fronteira; 1990.

5. Blessmann EJ. Corporeidade e envelhecimento: o significado do corpo na velhice. Estud Interdiscip Envelhec 2004;6:21-39.

6. Santos IE, Dias CMSB. Homem idoso: vivência de papéis desempenhados ao longo do ciclo vital da família. Aletheia 2008;27(1):98-110.

7. Jimenez M. O que é estética? São Leopoldo: Unisinos; 1999.

8. Moreira V, Nogueira FNN. Do indesejável ao inevitável: a experiência vivida do estigma de envelhecer na contemporaneidade. Psicologia 2008;19(1):59-79.

9. Peat CM, Peyerl NL, Muehlenkamp JJ. Body image and eating disorders in older adults: a review. J Gen Psychol 2008;135(4):343-58.

10. Gatti BA. Grupo focal na pesquisa em ciências sociais e humanas. Brasília, DF: Líber; 2005.

11. Eco U. História da beleza. Rio de Janeiro: Record; 2012.

12. Duarte Junior JF. O que é Beleza. São Paulo: Brasiliense; 1991.

13. Ferreira FR. A produção de sentidos sobre a imagem do corpo. Interface 2008;12(26):471-83.

14. Rezende C, Coelho MC. Antropologia das emoções. Rio de Janeiro: FGV; 2010. 
15. Goldenberg M. Coroas: corpo, envelhecimento, casamento e infidelidade. Rio de Janeiro: Record; 2008.

16. Pereira MV. Contribuições para entender a experiência estética. Rev Lusófona Educ 2011;18(18):111-23.

17. Pitanga DA. Velhice na cultura contemporânea [Dissertação]. Recife: Universidade Católica de Pernambuco; 2006.

18. Mucida A. Escrita de uma memória que não se apaga: envelhecimento e velhice. Belo Horizonte: Autêntica; 2009.

19. Ludgleydson A, Sá ECN, Amaral EB. Corpo e velhice: um estudo das representações sociais entre homens idosos. Psicol Ciênc Prof 2011;31(3):468-81.

20. Guerra ACLC, Caldas CP. Dificuldades e recompensas no processo de envelhecimento: a percepção do sujeito idoso. Ciênc Saúde Coletiva 2010;15(6):2931-40.

21. Schneider RH, Irigaray TQ. O envelhecimento na atualidade: aspectos cronológicos, biológicos, psicológicos e sociais. Estud Psicol 2008;25(4):137-49.
22. Caldas CP, Thomaz AF. A velhice no olhar do outro: uma perspectiva do jovem sobre o que é ser velho. Rev. Kairós 2010;13(2):75-9.

23. Fernandes MGM, Garcia LG. O corpo envelhecido: percepção e vivência de mulheres idosas. Interface 2010;14(35):879-90.

24. Ribeiro LF. Qualidade de vida na terceira idade. Ágora 2010;17(2):75-80.

25. Spirduso WW. Dimensões físicas do envelhecimento. São Paulo: Manole; 2005.

26. Ferreira OGL, Maciel SC, Silva AO, Santos WS, Moreira MASP. O envelhecimento ativo sob o olhar de idosos funcionalmente independentes. Rev Esc Enferm USP 2010;44(4):1065-69.

27. Foucault M. História da sexualidade: o cuidado de si. Rio de Janeiro: Graal; 2007.

28. Foucault M. Hermenêutica do sujeito. São Paulo: Martins Fontes; 2010.

Received: July 18, 2016

Revised: October 10, 2016

Accepted: January 13, 2017 